\title{
Between Similarity and Distinction: Notes on the Iconography of Saint Wilgefortis in the Medieval and Early Modern Period
}

\author{
Silvia Marin Barutcieff \\ University of Bucharest, Romania \\ silviahmarin@yahoo.fr
}

\section{Abstract:}

This study is centred on Saint Wilgefortis, probably best known saint from the group of crucified maidens. The aim is to investigate a number of late medieval and early modern representations of the virgin who can be studied from the perspective of gender inversion. Starting from the origins of this theme of gender change, the elements underlying the transformation process will be analyzed, in the broader context whereby deformity was chosen as a means for gaining spiritual salvation. The saint's similarities with other holy figures will also be discussed, as well as the attributes ascribed to her by popular belief, during the abovementioned period.

Keywords: female sanctity; deformity; similarity; difference; medieval iconography; Saint Wilgefortis, Volto Santo. 


\title{
Between Similarity and Distinction: Notes on the Iconography of Saint Wilgefortis in the Medieval and Early Modern Period
}

\author{
Silvia Marin Barutcieff \\ University of Bucharest, Romania
}

\section{Introduction}

In both canonical and popular hagiography, the physical traits of a person who consecrated their life to Christ at the expense of their corporal integrity are meant to build up progressively and complete their exceptional destiny. Since the beginning of the last century, researchers of the lives of saints have highlighted the fact that a martyr stands for a typology, not for an individuality. ${ }^{1}$ Within this paradigm, there are two categories of saints, regardless of them being martyrs or blessed. The category of martyrs includes those who stood under a positive sign from the very beginning, being either born by Christian parents or converted as a result of a revelation, a dream, or an encounter with another Christian who helped them acquire a new spiritual status. The second category consists of martyrs who were persecutors themselves or had a negative lifestyle. Their sinful existence was interrupted by a momentous event which led to their conversion to Christianity.

Female hagiography is based on the biographies of venerable women such as Mary of Magdala and Mary of Egypt. Their devotion to divine transcendence generated a pattern recognizable in the lives of certain female martyrs. In contrast to ordinary Christian identity, the sacred alterity reflected in the Lives of Saints, especially in the case of female saints, is also built on references related to their beauty. Should

\footnotetext{
${ }^{1}$ Hippolyte Delehaye, Les Passions des martyrs et les genres littéraires (Brussels: Bureau de la Société des Bollandistes, 2nd ed., 1966), 240.
} 
one only consider Legenda Aurea, the most popular hagiographic source of the late Middle Ages, the recurrence of the physical exceptionality of many female saints it observable (related to saints from Agnes to the three daughters of Sophia, or from Margaret of Antioch to Christina and Daria). Even in extremely synthetic narrative constructions, such as the hagiographies included in Jacopo da Varazze's anthology, beautiful physiognomies are often mentioned..$^{2}$ Regardless of how beauty is used in the narrative, it represents one of the distinctive traits of female saints.

However, within the broader frame of medieval religious texts which connect to the concept of beauty, a counter-image is also observable: the renouncement of beauty as a premise for the redemption of the soul. This happens in hagiographies where saints disfigure themselves in order to prevent any suitor's attempt to divert them from the mystical marriage to Christ.

Based on these considerations, this study will investigate the semantic transformations undergone by the figure of Saint Wilgefortis during the Late Middle Ages and Early Modern Period. I provide an overview of the consequences of the artistic metamorphosis which led to the emergence of a new female saint in Western Christianity, as well as the elements of cultural transfer involved in this process. The study will also stress the implications of associating Wilgefortis to similar saints of the iconographic programme.

\section{From Modern Times to Middle Ages: Companions in Female Hagiography}

The main altar in the St. Wilgefortis Church in Neufahrn (close to the German city of Freising) holds a crucifix with a surprising history. In some researchers' opinion, ${ }^{3}$ the crucifix (a sculpture of Romanesque origin) was brought in its current place from the Freising monastery in the fifteenth century. In 1580, the crucifix was damaged by a fire. Consequently, at the beginning of the seventeenth century, the

\footnotetext{
2 Jacques de Voragine, La légende dorée, transl. from Latin by Teodor de Wyzewa (Paris: Editions du Seuil, 1998). References to the female saints' beauty can be found on the following pages of the edition: 97 (Agnes), Agatha (146), Sophia (285), Margaret of Antioch (334), Christina (349), Daria (595).

3 Peter B. Steiner apud Ernest Lang, Kirchen der Pfarrei Neufahrn bei Freising (Regensburg: Schnell \& Steiner, 2002), 4.
} 
sculpture underwent several interventions, in accordance to the Baroque atmosphere of the time. Along with the corruption of the material, the religious identity also switched from the ordinary representation of the crucified Christ to that of a female martyr, namely Wilgefortis. ${ }^{4}$ The piece is still preserved today, via its second titular saint (St. Wilgefortis), highlighting the unusual transformation. In the centre of the main altar, on the phylactery at the basis of the cross, one can notice not only the year of this gender and religious metamorphosis, but also the names pertaining to the new saint: Wilgefortis, Liberata, Kümmernis.

Research conducted in the twentieth century signalled the nominal variety related to the saint's identity change. ${ }^{5}$ Hanged on the cross, the saint was attested with the name of Wilgefortis (according to some, from the Latin virgo fortis = "strong virgin;" for others from Hilge Vartz/Fratz. = "Holy Face") $)$, Kümmernis (Germ. Kummer = "anguish," "pain," "bitterness"), Ontcommer, (Dutch Ontkomen = "break free from"), Liberata (French (se) libérer = "free oneself"), Liberdade (Port.), Uncumber (Engl.) or, in Slavic regions, Frasobliwa (Pl.) = "sorrowful," Starosta $(\mathrm{Cz})=$ "senior." "elder."

The devoutness to this virgin was expressed to a certain extent until the twentieth century, when the reformation of the universal Catholic calendar took place and she ceased to be celebrated. ${ }^{8}$ Although she was especially famous in Netherlands, Bavaria and Tyrol during the medieval and modern periods, she also became a familiar religious figure outside these territories, as her iconographic representations in France, Spain, Pomerania, and Bohemia testify.

${ }^{4}$ Ibidem, 2.

5 Louis Réau, Iconographie de l'art chrétien, t. 3 - Iconographie des saints (Paris: Presses Universitaires de France, 1959), 1343.

${ }^{6}$ Jane Tibbett Schulenburg, Forgetful of Their Sex: Female Sanctity and Society, ca 510-1100 (Chicago: University of Chicago, 1998), 462.

${ }^{7}$ Regine Schweizer-Vüllers, Die Heilige am Kreuz. Studien zum weiblichen Gottesbild im späten Mittelalter und in der Barockezeit (New York: Peter Lang, 1999), 62.

8 In the universal calendar of the Roman-Catholic Church, Saint Wilgefortis used to be celebrated on the $20^{\text {th }}$ of July, along with another virgin, Margaret of Antioch. See Michael Ott, "Wilgefortis," vol. 15, (New York: Robert Appleton Company, 1912), See: http: // www.newadvent.org/cathen/15622a.htm (last time accessed: 23 April 2018). Following the Church reform in 1969, she was expelled from the calendar. See also Albert Sleumer, Kirchenlateinisches Wörterbuch. Unter unfassendster Mitarbeit von Joseph Schmid (New York: Georg Olms, 2011), 833. 
In 1477, The Book of Hours, conceived for Mary of Bourgogne, presented an illustrated version of the hagiography. In it, Kümmernis appeared as the unhappy offspring of a father who sent her to death on account of having refused a forced marriage. More than half a century before, a different Flemish Horae revealed her with her legs firmly tied with a rope, as a prisoner of the same persecuting parent. According to certain hagiographic versions, Wilgefortis was one of the seven beautiful and bright ${ }^{9}$ daughters of the Portugal king, ${ }^{10}$ who was responsible for the young woman's crucifixion, as she refused to marry the suitor chosen by her father ${ }^{11}$ and instead opted to devote her life to the Heavenly Groom. ${ }^{12}$ This aspiration to hieratic spaces puts the saint within the paradigm of crucified female saints, along with Julia of Corsica and Eulalia. ${ }^{13}$ One of the oldest such iconographical representation can be seen on the twelfth-century capital of the former church San Salvatore from Brescia. ${ }^{14}$ Saint Julia was immortalised there as her soul was leaving her frail body in the shape of a dove. Starting with the fresco in the Santa Maria in Solario oratory from the Santa Giulia Monastery which honours the martyr, in the same Lombardian city of Brescia, and going to more recent artistic illustrations, such as that of Gabriel Cornelius von Max of 1865, one may notice an interest

${ }^{9}$ Martin Kraatz, "Die Heilige Kümmernis und ihre Erforschung zwischen Legende und Wirklichkeit," in Am Kreuz - eine Frau. Anfänge - Abhängigkeiten - Aktualisierungen, ed. Sigrid Glockzin-Beuer, Martin Kraatz (Münster: LIT, 2003), 12.

10 Regine Schweizer-Vüllers, Die Heilige am Kreuг, 34; Norbert Wolf, Der Macht der Heiligen und ihrer Bilder (Stuttgart: Reclam, 2004), 233. Christina M. Carlson talks about several versions of the story in which the king has either 7 or 9 children, sometimes only daughters. See "Wilgefortis," in Holy People of the World: A Cross-Cultural Encyclopedia, ed. Phyllis G. Jestice (Oxford: ABC Clio, 2004), 918. David Hugh Farmer refers to a report of Saint Gregory the Great, which mentioned the saint for the first time. See Oxford Dictionary of Saints, transl. in Rom. by Mihai C. Udma and Elena Burlacu (Bucharest: Univers Enciclopedic, 1999), 537.

${ }^{11}$ In some versions the suitor was the king of Sicily. Ibidem, 12.

12 Gregory G. Bolich, Conversing on Gender. A Primer for Entering Dialog (Raleigh: Psyche’s Press, 2007), 434; Donald L. Boisvert, Carly Daniel-Hughes, "Introduction," in The Bloomsbury Reader in Religion, Sexuality and Gender, ed. Donald L. Boisvert (New York: Bloomsbury, 2016), 1.

13 For more details on the iconography of Saint Julia of Corsica and Saint Eulalia, see one of Jürgen Zänker's studies in the vol. Crucifixae. Frauen am Kreuz (Berlin: Gebr. Mann, 1998).

14 San Salvatore Church or Santa Giulia is a former monastic complex from Brescia turned into a museum. 
for a kind of ordeal which mirrors Christ's model. ${ }^{15}$ Apart from the crucifixion episode, what do all these solitary female characters have in common? First, an endless love for Christ, which prevents them from an earthly marriage; second, the persecution exerted with the permission of a male authority, a father (for Wilgefortis) or the ruler of a land (for Julia). Last but not least, both Kümmernis and another representative character, Galla of Rome, widow since her youth, go through significant episodes of disfigurement. ${ }^{16}$ Both saints ask God for the defacement of their beauty. The result is swift and irrevocable; they were endowed with a beard; in other words, they were deprived of a female attribute- the smooth and hairless facial skin. The new masculine element does not only bring physical ugliness, but also relegates them into a category of deformity. Paradoxically, the wish to avoid a marital relationship by stultification captures the viewer's attention even more.

\section{Gender Inversion: From Christ the Crucified to the Holy Virgin Kümmernis}

In the case of Wilgefortis, the reasons for renouncing female grace by means of gender inversion and the adoption of a hirsute appearance may be explained by the artists' misunderstanding of the image of Volto Santo ("Saintly Face"), a mediaeval crucifix kept in the tabernacle (tempietto $)^{17}$ of Saint Martin Cathedral from Lucca. ${ }^{18}$ Mentioned in the early years of the twelfth century, it was probably replaced by a new one in the following century. ${ }^{19}$ Despite some differences of opinion, art historians estimate that the carving of Crucified Christ is not older than the twelfth-thirteenth centuries. ${ }^{20}$ A legend from Relation leobiniana ${ }^{21}$ asserts that the crucifix was carved in wood by Nicodemus himself;

\footnotetext{
15 See also the alabaster carving of Eulalia in the crypt of Barcelona Cathedral.

16 Ulrike Wörner, Fran am Kreuz, Eine neu entdeckte Kultfigur (Salzweg: Kultur im Landkreis Passau, 2015), 27.

17 The tabernacle in the nave was created in 1484 by Matteo Civitali, a sculptor and architect from Lucca.

18 The Cathedral of Sf. Martin from Lucca, built in the eleventh-fifteenth centuries.

19 Ilse E. Friesen, The Female Crucifix: Images of St. Wilgefortis since the Middle Ages (Waterloo: Wilfried Laurier University Press, 2001), 12.

20 Wolf, Der Macht der Heiligen, 233.

21 "Volto Santo," in The Grove Encyclopedia of Medieval Architecture, ed. Colum P. Hourihane (Oxford \& New York: Oxford University Press, 2012), vol. 2, 331.
} 
however, without the angels' contribution, the sacred object would not have been so precious. The merchants from Lucca were responsible for the dissemination of the legend, as many of them were active in the Netherlands, France, and England. For instance, in Brugge (where Wilgefortis was arduously honoured during the fourteenth and following centuries) the Rapondi family dwelt and owned a chapel with the image of Volto Santo. ${ }^{22}$

The Parisian manuscripts of about 1400 include narrative cycles referring to the development, translation, and miracles of the Saintly Face in which the book merchant Jacques Rapondi may have been involved. ${ }^{23}$

Over time, candle smoke darkened entire work from Lucca. On the occasion of the Holy Cross celebrations during the night of September 13/14, the Christ of the Cathedral of Tuscany received a velvet skirt adorned with lilies, a golden necklace, a luxurious crown and other jewellery. These elements may have contributed to the distortion of the carving's initial identity, i.e. a divine object peddled from a pilgrimage to the Holy Land by Bishop Gualfredo and settled in Lucca by divine will. ${ }^{24}$ Their existence may be certified by a fresco from the beginning of the sixteenth century, signed by Amico Aspertini in the San Frediano Basilica. ${ }^{25}$ Amico Aspertini created an episode called the Translation of the Volto Santo in which there are a series of elements to be resumed in the bearded maid's subsequent iconography. Another artist responsible for the peddling of confusion, especially in the German area, is Hans

\footnotetext{
22 Wörner, Frau am Kreu₹, 63.

23 Hilary Maddocks assumes that Jacques Rapondi, dealing with illuminated manuscripts at that time and because of his origin in Lucca may have been responsible for the dissemination of the legend in certain regions. A Parisian miniature held at Vatican displays the image from the Tuscan city. See the image reproduced by Hilary Maddocks, Vatican City, BAV, MS. Pal. Lat. 1988, fol. 13r, "Légende du Saint-Voult," in Patrons, Authors and Workshops: Books and Book Production in Paris around 1400, ed. Godfried Croenen, Peter F. Ainsworth (Paris: Peeters, 2006).

24 The legend assumes that the crucifix was the bone of contention between the Christians from Lucca and those from Luni. Pulled by an ox-wagon, the sculpture was carried to Lucca. This episode was traditionally placed in the eighth century. See Joan Carroll Cruz, Miraculous Images of Our Lord: Famous Catholic Statues, Portraits and Crucifixes (Charlotte: Tan Books, 1995), chapter 14.

25 Amico Aspertini of Bologna painted the fresco known as the Translation of the Volto Santo (1508-1509) in the Chapel of Saint Augustine, San Frediano Basilica from Lucca, Italy.
} 
Burgkmair. In his1507 engraving - although he noted Die bildnis zu Lucca inside the image - the engraver of Augsburg also included the history of Sankt Kümmernus in the composition. ${ }^{26}$

Echoes of the German crucifix from Lucca reverberated throughout the German territories in the early modern period. In the Swabian picture commissioned by the Kröl family in the fourteenth century, ${ }^{27}$ an open golden ring with lily-shaped endings resembling the one from Aspertini's work encircles the figure of the crucified figure. The ring can also be found in the frescoes of Parma (fig. 1) and Weissenburg $i$. B. as well as in the oil painting from Stadtmuseum Lindau. In Kwidsy $n^{28}$ (Poland), the painter used only the upper part of the ring for aesthetic reasons. A long dark-shaded shirt is added to Kümmernis' garment. One can notice two types of clothes which were mostly assigned to her: the dark brown/grey long-sleeved tunic, which can be seen in the frescoes from Parma, ${ }^{29}$ Bregenz $^{30}$ (fig. 2), Garmisch, ${ }^{31}$ Bamberg, ${ }^{32}$ Ravensburg $^{33}$ (fig. 3), Düsseldorf, ${ }^{34}$ Rosenheim, ${ }^{35}$ Rain am Lech, ${ }^{36}$

26 Regine Schweizer-Vüllers, Die Heilige am Kreuz, 21-22; Martin Kraatz, Die Heilige Kümmernis, 17; Ilse E. Friesen, "Virgo Fortis: Images of the Crucified Virgin Saint in Medieval Art," in Virginity Revisited: Configurations of the Unpossessed Body, ed. Bonnie MacLachlan, Judith Fletcher (Toronto: University of Toronto Press, 2007), 116-120.

27 The work is preserved at the Lindau museum, Haus zum Cavazzen, inventory no. ÖAKD 2. The work holds an inscription with the initials of the donor, who was identified as one of the members of a famous Swabian family, the Kröll (Krel) family. See explanations from the museum. An altarpiece painted by Alfred Dürer, with the family's coat of arms and Oswolt Krel's portrait, can be found in Alte Pinakothek, München.

28 The Cathedral of St. John the Evanghelist, Kwidzyn, Poland, Pomerania region, wall painting from the fifteenth-sixteenth centuries.

29 The Baptistery from Parma, built between 1196 and 1216, designed by Benedetto Antelami, fresco from the fourteenth century.

30 The Chapel of Saint Martin from Martinsturm, Bregenz, mural painting from 1363. For the dating of the work, see Jürgen Michler, Gotische Wandmalerei am Bodensee (Friedrischafen: Robert Gessler, 1992), 30.

31 The old St. Martin Church, Garmisch-Partenkirchen, mural painting from the beginning of the fifteenth century, Eastern wall of the nave.

32 Church of the Dominican Monastery, Bamberg, mural painting from 1402-1403.

33 Ravensburg, former Carmelite monastery, at present Evangelical parish; Wilgefortis, choir, northern wall, painting from 1470.

${ }^{34}$ Düsseldorf, Saint Lambertus Basilica, wall painting from 1460.

35 Rosenheim, Church of the Holy Ghost, St. Wolfgang Chapel, painting from midfifteenth century.

${ }^{36}$ Rain am Lech, Catholic Church of St. John the Baptist, mural painting, after 1480. 
Auhausen, ${ }^{37}$ Weissenburg i. B., ${ }^{38}$ Erlangen, ${ }^{39}$ Lindau $^{40}$ etc), under the influence of the Christ from Lucca. ${ }^{41}$ According to Ilse E. Friesen, ${ }^{42}$ this dress follows a Syro-Palestinian tradition and shows the process of transition from a sacred object of crucifixion to the genesis of a holy figure. The celebratory attire received by the crucifix of Lucca in September each year also played a role in the metamorphosis, as the lily pattern gradually moved on to the virgin's clothes, being especially preferred in Baroque and later representations (Monastery Stetten in Gnadental, ${ }^{43} \mathrm{Hollenbach}^{44}$ ). There are also some chromatic variations, not devoid of significance. Starting from the sixteenth century, representations of the saint in a red or (seldom) white habit ${ }^{45}$ may be encountered. The red garment one was probably the result of contamination with the dress worn by St. Julia of Corsica, as it can be seen in the central panel of Hieronymus Bosch's triptych (15001504), ${ }^{46}$ whereas in Kummernis' case it is especially noticed during the seventeenth-nineteenth centuries (Hilgertshausen - fig. 4, Alttöting ${ }^{47}$ ). Nevertheless, white is the colour showing a change in a saint's status, a transition to another level, of initiation and enlightenment, ${ }^{48}$ as we may notice in Wilgefortis' clothes at Kwizdyn.

37 Auhausen, St. Maria Church, former Benedictine church, at present Evangelical parish, painting of Wilgefortis on a pillar on the north part, sixteenth century.

38 Weissenburg i. B., Carmelite Church, fresco with Wilgefortis from the last quarter of the fourteenth century.

${ }^{39}$ Erlangen-Eltersdorf, St. Egidius Evangelical Church, altarpiece from 1513.

${ }^{40}$ Lindau, Haus Zum Cavazzen, oil painting, sixteenth century.

41 This type can be found in the Crucifix of Imervard, from Brunswick Cathedral, made around 1150 .

42 Ilse E. Friesen, The Female Crucifix, 64.

43 Stetten Monastery in Gnadenthal, Hechingen, Baden-Württemberg, restored in the eighteenth century.

${ }^{44}$ Saint Peter and Paul Church from Hollenbach, Bavaria, baroque sculpture, eighteenth century (?).

45 One such example is an ex-voto preserved in Germanisches Nationalmuseum from Nuremberg (see infra).

${ }^{46}$ Hieronymus Bosch, St. Julia, 1500-1504, oil painting, Palazzo Ducale, Venice.

47 Altötting, Bavaria, Cathedral of Saints Philip and James, oil painting, eighteenth century.

48 Dictionnaire des symbols, éd., Jean Chevalier and Alain Gheerbrant (Paris: Robert Laffont, 1984), vol. 1, transl. in Rom. by Micaela Slăvescu, Laurentiu Zoicas et al. (Bucharest: Artemis, 1994), 75-78. 
As a consequence of distortion and cultural transfer, at the end of the Middle Ages, numerous images came to visually celebrate a martyr venerated as a patron of unhappiness in marriage experienced by women who dreamt about escaping their husbands' aggressiveness. The prayer formula was "Uncumber me of him"! (Fr. « Débarasse-moi de lui »!, (It.) "Liberami da lui"!), ${ }^{49}$ a reason why Wilgefortis came to be celebrated in different cultural spaces as the saviour from cruel marriages. Ulrike Wöerner's observes that the growing veneration of the virgin is consonant with a new devotional movement attested in the thirteenth-fourteenth centuries, supported by the so-called beguines, solitary women (widows, separated from their husbands or single). These lovers of Christ would not withdraw to a nunnery, but choose to live in a community under the protection of a city authority, having the right to earn their existence without any encumbrance.

There are, however, certain reports which show that Wilgefortis did not solely have female audience. Aside from unhappy wives or young women who firmly avoided marriage, there were also men who strived to express their gratitude, as it is reflected by the subject's iconography. A legend telling the story of the salvation of an aggrieved man was present in the German part of Switzerland.

A musician had been accused of having committed a crime and, as he was led to prison, he escaped and hid in a church which also hosted a sculpture of Wilgefortis. The men threw himself at her feet and presently, in order to prove his innocence, the saint let go one of her shoes. ${ }^{50}$

Numerous artistic works illustrate the moment when, knelt at the foot of the cross, the man plays the violin to express his gratitude to Kümmernis. Furthermore, in the early frescoes of the fourteenth century (in the baptistery of Parma, in the church oratory from Weissenburg or Bregenz), but also in the fifteenth century (Rosenheim, Düsseldorf - fig. 5, etc), the musician is shown by the saint's right side. ${ }^{51}$ Sketches and engravings from the sixteenth century hold the

49 See Medieval Folkelore. An Encyclopaedia of Myths, Legends, Tales, Beliefs, and Customs, ed. Carl Lindahl, John McNamara, John Lindow (Oxford: ABC-Clio, 2000), 857-858.

${ }^{50}$ Joris-Karl Huysmans, "Sainte Débarras," in De tout, chap. XXII (Paris: P. V. Stock, 1902), www. huysmans.org/detout/detout22.htm (Last accessed: 03 April 2017).

51 The left side of the viewer. The musician can also be seen in the engraving of Hans Springinklee, 1513. Cf. Norbert Wolf, Die Macht der Heiligen, 233. One can find 
same reference. ${ }^{52}$ Moreover, the brothers Grimm's Anthology of Fairy Tales mentions a similar version. In their version, it is reported that a poor violinist entered a church and sang to the crucified virgin. In order to pay him, Kümmernis let go of one of her golden shoes. Soon afterwards, the man was caught and accused of theft. Returning to the crucifix, the accused prayed fervently to be discharged, and the saint proved his innocence by offering him the other shoe. ${ }^{53}$ It is likely that this interpretation of the image only became popular in the modern period. In an ex-voto commissioned in the honour of Kümmernis by the community of Hilgertshausen in 1689, the saint is painted barefoot, with her second golden shoe beside the violinist's praying hands. Further on, the bearded virgin remained a highly popular figure in German territories as one can observe from the many images and objects dedicated to her in seventeenth, eighteenth, and nineteenth centuries. ${ }^{54}$

representations in which, on the other side of the fiddler, the painting's donor was also represented (an example is the image in the Dominican Church of Bamberg). See Stephanie Hoyer, Die W andmalereien der Dominikaner in Bamberg. Kunsttechnologische Analyse des Malereibestandes und beispielhafte Vermittlung complexer Zeitschichten (Bamberg: Otto Friedrich Universität, 2009, inaug. dissert, I), 100-101.

52 See ill. no. 23 reproduced in Regine Schweizer-Vüllers, Die Heilige am Kren : The musician can also be seen in the engraving from 1513, made by Hans Springinklee. Cf. Norbert Wolf, Der Macht der Heiligen, 232.

53 The legend was published as no. 66 in 1815, but not in 1819. According to Jack Zipes, The Complete Fairy-Tales of the Brothers Grimm (New York: Bantam Books, 2002), $3^{\text {rd }}$ edition, the tale no. 239, Saint Solicitous.

${ }^{54} \mathrm{Ex}$-votos with Wilgefortis are preserved in religious edifices such as the pilgrimage church of Neufahrn bei Freising, where one can find ex-votos from 1733 and 1840. In the baroque church of Andechs Monastery an ex-voto from 1678 was placed on the wall of the nave, among tens of ex-votos dedicated to Virgin Mary. Museums of Bavaria also possess a few examples of the piety towards Kümmernis. In Germanisches Nationalmuseum of Nuremberg, the section on popular art contains no less than 8 exvotos of the saint (main collection from 2015). The same museum is the custodian of a wooden sculpture from Lower Rhine, dated around 1530. This object is obviously related with Volto santo, plainly visible in the long-sleeved dark tunic and the crown as an emblem of Wilgefortis. For the ex-votos of the Museum Kloster Asbach, see Ulrike Wörner, Frau am Kreuz, 104-105, 124-125. Around 1960, the Austrian scholar Leopold Kretzenbacher investigated the modern popular devotion in conjunction with regions of Carinthia and Styria. See Leopold Kretzenbacher, Heimat im Volksbarock. Kulturbistorische Wanderungen in den Südostalpenländern (Klagenfurt: Verlag des Landesmuseums für Kärnten, 1961), 129-136. A more recent research is that of Ilse E. 


\section{Skills and symbolical proximities in the medieval Christian sanctoral}

The miracles expected from Wilgefortis were not confined to marital relationships and the protection of musicians and craftsmen; 55 therapeutic outcomes were also sought. In Normandy, for instance, her aid was invoked in order to cure sick children, female infertility, stomach diseases, and anaemia. Conquered by the saint's history and popularity in the French rural areas, in 1902, the writer Joris-Karl Huysmans dedicated her two chapters in his volume of journalism $D e$ tout. ${ }^{56}$ The virgin's skills range from the power to keep crops unharmed, to the ability to save animals ${ }^{57}$ and to protect travellers. ${ }^{58}$ These skills, along with her martyrdom, propelled Kümmernis among the saints who mediated the dying on their deathbeds. ${ }^{59}$ Her qualities as mediator and as a delegate of the Divinity, were preserved in early modern works. Thus, in the church of Hilgertshausen, the text from 1689 which accompanies the image reminds of her role as spiritual advisor and support in critical situations.

Owing to her bizarre beard and moustache, Wilgefortis joins another paradigm that of hermit saints, the most famous of them being Mary Magdalene and Mary of Egypt. On several occasions, medieval iconography renders the latter in the hypostasis of a nude female, either camouflaged by long thick hair waving around like a cloak or covered by excessive body hair. In the Freising Diocesan Museum, a piece by

Friesen. See "Die Heilige Kümmernis in Tirol," in Am Kreuz - eine Frau. Anfänge Abbängigkeiten - Aktualisierungen, 36-54.

55 Ilse E. Friesen, The Female Crucifix, 63.

56 Joris Karl Huysmans, “Sainte Débarras," 2017. http:/ / www.litteratureaudio.com/livre-audio-gratuit-mp3/huysmans-joris-karl-saintedebarras-les-gobelins.html.

57 Ilse E. Friesen analyses the modern cult of the saint in certain regions of Austria and in southern Germany. She mentions ex-votos granted to churches in the eighteenth and nineteenth centuries, as a token of gratitude for Wilgefortis' assistance in saving domestic animals in danger. See The Female Crucifix, 63.

58 David William, Deformed discourse. The function of the monster in medieval thought and literature (Montreal: McGill-Queen's University Press, 1996), 309.

${ }^{59}$ Ilse E. Friesen, "Saints as Helpers in Dying: The Hairy Women Mary Magdalene, Mary of Egypt, and Wilgefortis in the Iconography of the Late Middle Ages," in Death and Dying in the Middle Ages, ed. Edelgard E. DuBruck, Barbara I. Gusick (New York: Peter Lang, 1999), 245. 
Jan Polack dating from the first decade of the sixteenth century, brings to attention Mary of Magdala, over whose body the angels are waving an immaculate cloth. The sustained career of this iconographic type can be perceived in certain sanctuaries which preserve more copies belonging to distinct layers of the mural painting. For instance, the frescoes of the San Zeno Basilica of Verona show eight occurrences of the saint shrouded in her long hair falling to her ankles. One of the most beautiful copies executed by Tilman Riemenschneider in the last decade of the fifteenth century brings to light this indomitable and wild identity. Kept at the National Museum of Bavaria, the wood carving shows Magdalene praying, surrounded by six angels, which alludes to the hagiographic episode from the Legenda Aurea about the saint's ascetic life in the Alpes-Maritimes. ${ }^{60}$

Like Wilgefortis, Mary Magdalene and Mary of Egypt strive to silence their female grace and alter their gender, as they aspire to reach a place where gender is devoid of any significance. The power derived from this and from a freely-assumed metamorphosis stimulated the veneration of the three saints as patrons of atonement. ${ }^{61} \mathrm{We}$ are presented, thus, with a sacred female figure glorified for freedom, assistance in travelling, and mercy shown to the medieval Christian on the threshold of death, a saint who not only loves Christ but also manifests herself as a female saviour. Wilgefortis' juxtaposition to Saint John the Evangelist in the iconographic programme of the church from Kwidzyn and the presence of the chalice within the frame of the two scenes also highlight her liturgical significance. Another connection with the Mass is articulated by her position in certain edifices, either in the choir or nearby (Ravensburg, Garmisch, Neufahrn). This also underlines her kinship with Crucifixion. In both cases, from the perspective of eschatological and liturgical semantics, Kümmernis reveals herself as a companion of Saint Christopher, the famous sacred giant of the Catholic world or, as he appears in the Orthodox version, a handsome and humble young man. Saddened by the fact that he had become an unwilling seducer of women, he prays the Divinity to be redeemed from the beauty of his exquisite face. His imploration is heard and soon afterwards he would become the happy bearer of a

${ }^{60}$ Jacques de Voragine, La légende dorée, 338-347.

61 Ibidem, 245. 
zoomorphic head. ${ }^{62}$ The two saints' affinities are also revealed in the assistance granted to travellers and their protection from sudden death. In the Parish of Rain am Lech (fig. 6), the two saints stand over the entrance door: ${ }^{63}$ Christopher with his expression of gentle giant and Wilgefortis in the already well-known hypostasis of a bearded crucified female. To them and to others alike, the destruction of physical beauty is sought as an escape from the body's instability. Although longing for the hidden backstage, Wilgefortis, the bearded virgin, steps into forefront of attention without having a choice.

\section{Conclusions}

For saints discussed before and their destruction of beauty is meant as an attempt to escape from the trap of an attractive figure. Although from an inner spiritual perspective, the disfigurement spurs them to paradise, while only by dying the heavenly body can be born, the effect is reversed in the viewer's external perception. By displaying an abnormal facial element, in an effort to hide their grace at all costs, the canon of the visually-anonymous saints is abandoned.

Wilgefortis' hagiography is late dated, thus her visual representations only become increasingly frequent in the sixteenth century. More interestingly, in certain areas such as Bavaria, her notoriety outlasted the periods of the Reformation and the Counter-Reformation, so that the collective imaginary retained the figure of this bearded virgin until the twilight of the modern period. Her physiognomic inadequacy, as a differentiating element, renders her figure relevant to the modern canon.

Reaching back to the thirteenth and fourteenth centuries, her hagiographic metamorphosis seems to follow a pattern comparable to that of Saint Christopher. The image of the Christ-bearer underwent a similar semantic transformation; moreover, it occurred during the same period. Most likely at the beginning of the eighteenth century, Saint Christopher's name generated his image as a bearer of Christ, and this

62 For the Eastern iconographic versions of Saint Christopher, see Silvia Marin Barutcieff, Hristofor: chipurile unui sfânt fără chip. Reprezentările din cultura românească veche și sursele lor [Christopher: Faces of a Faceless Saint. Representations in Medieval and Modern Romanian Culture and Their Sources](Cluj-Napoca: Mega, 2014).

63 In St. Lambertus Church Düsseldorf, the fresco of Wilgefortis is located also on the top of the entrance. 
image was subsequently re-encoded and converted into a new hagiographic legend that supplanted the older hagiography. This is a typical medieval instance of a metamorphosis that is intended to maintain, in the collective mindset, a paragon of exemplarity constructed by similitude.

Finally, we can note that the iconographic syntax itself plays an important role in securing certain symbolic connotations. Within the sacred space, Wilgefortis is most often placed alongside other figures belonging to the same paradigms as herself - the eschatological and the liturgical ones. Certainly, to the medieval mind this is a comforting association, indicating that the deformed body may actually assist in the elevation of the soul.

\section{References}

\section{Primary sources}

Huysman, Joris-Karl. “Sainte Débarras.” In De tout, chap. XXII. Paris: P. V. Stock, 1902, www. huysmans.org/detout/detout22.htm.

De Voragine, Jacques. La légende dorée. Transl. from Latin by Teodor de Wyzewa. Paris: Editions du Seuil, 1998.

Zipes, Jack, ed. The Complete Fairy-Tales of the Brothers Grimm $3^{\text {rd }}$ edition. New York: Bantam Books, 2002.

\section{Secondary Literature}

Bolich, Gregory G. Conversing on Gender. A Primer for Entering Dialog. Raleigh: Psyche's Press, 2007.

Boisvert, Donald L., ed. The Bloomsbury Reader in Religion, Sexuality and Gender. New York: Bloomsbury, 2016.

Carlson, Christina M. "Wilgefortis," 918. In Holy People of the World: A Cross-Cultural Encyclopaedia. Ed. Phyllis G. Jestice, Oxford: ABC Clio, 2004.

Chevalier, Jean and Alain Gheerbrant, ed. Dictionnaire des symbols, vol. 1. Paris: Robert Laffont, 1984. Transl. in Rom. by Micaela Slăvescu, Laurentiu Zoicas et al. Bucharest: Artemis, 1994.

Cruz, Joan Carroll. Miraculous Images of Our Lord: Famous Catholic Statues, Portraits and Crucifixes. Charlotte: Tan Books, 1995. 
Delehaye, Hippolyte. Les Passions des martyrs et les genres littéraires. Bruxelles: Bureau de la Société des Bollandistes, $2^{\text {nd }}$ ed., 1966.

Farmer, David Hugh. Oxford Dictionary of Saints, Oxford: Oxford University Press, 1978. Transl. in Rom. by Mihai C. Udma and Elena Burlacu. Bucharest: Univers Enciclopedic, 1999.

Friesen, Ilse E. "Saints as helpers in Dying: The Hairy Women Mary Magdalene, Mary of Egypt, and Wilgefortis in the Iconography of the Late Middle Ages." In Death and Dying in the Middle Ages. Ed. Edelgard E. DuBruck, Barbara I. Gusick, 239-256. New York: Peter Lang, 1999.

.. The Female Crucifix: Images of St. Wilgefortis since the Middle Ages. Waterloo: Wilfried Laurier University Press, 2001.

. "Virgo Fortis: Images of the Crucified Virgin Saint in Medieval Art." In Virginity Revisited: Configurations of the Unpossessed Body. Ed. Bonnie MacLachlan, Judith Fletcher, 116-127. Toronto: University of Toronto Press, 2007.

Kraatz, Martin. "Die Heilige Kümmernis und ihre Erforschung zwischen Legenden und Witklichkeit." In Am Kreuz - ine Frau. Anfänge - Abhängigkeiten - Aktualisierungen. Ed. Sigrid GlockzinBeuer, Martin Kraatz, 10-20. Münster: LIT, 2003.

Kretzenbacher, Leopold. Heimat in Volksbarock. Kulturbistorische Wanderungen in den Südostalpenländern. Klagenfurt: Verlag des Landesmuseum für Kärnten, 1961..

Lang, Ernest. Kirchen der Pfarrei Neufahrn bei Freising. Regensburg: Schnell \& Steiner, 2002.

Lindahl, Carl, John McNamara, John Lindow, ed. Medieval Folklore. An Encyclopedia of Myths, Legends, Tales, Beliefs, and Customs. Oxford: ABCClio, 2000.

Maddocks, Hilary. "Légende du Saint-Voult." In Patrons, Authors and Workshops: Books and Book Production in Paris around 1400. Ed. Godfried Croenen, Peter F. Ainsworth, 91-122. Paris: Peeters, 2006. Marin Barutcieff, Silvia. Hristofor: chipurile unui sfânt fără chip. Reprezentările din cultura românească veche și sursele lor [Christopher: Faces of a Faceless Saint. Representations in Medieval and Modern Romanian Culture and their Sources]. Cluj-Napoca: Mega, 2014.

Michler, Jürgen. Gotische Wandmalerei am Bodensee. Friedrischafen: Robert Gessler, 1992. 
Réau, Louis. Iconographie de l'art chrétien, t. 3 - Iconographie des saints. Paris: Presses Universitaires de France, 1959.

Schweizer-Vüllers, Regine. Die Heilige am Krenz: Studien zum weiblichen Gottesbild im späten Mittelalter und in der Barockzeit. New York: Peter Lang, 1999.

Tibbett Schulenburg, Jane. Forgetful of Their Sex: Female Sanctity and Society, ca 510-1100. Chicago: University of Chicago, 1998.

"Volto Santo." In The Grove Encyclopedia of Medieval Architecture. Ed. Colum P. Hourihane, vol. 2. Oxford: Oxford University Press, 2012. William, David. Deformed Discourse. The Function of the Monster in Medieval Thought and Literature. Montreal: McGill-Queen's University Press, 1996.

Wolf, Norbert. Der Macht der Heiligen und ibrer Bilden. Stuttgart: Reclam, 2004.

Wörner, Ulrike. Frau am Kreuz, Eine neu entedckte kultfigur. Salzweg: Kultur im Landkreis Passau, 2015.

Zänker, Jürgen. Crucifixae. Frauen am Kreuz. Berlin: Gebr. Mann, 1998. 


\section{Illustrations}

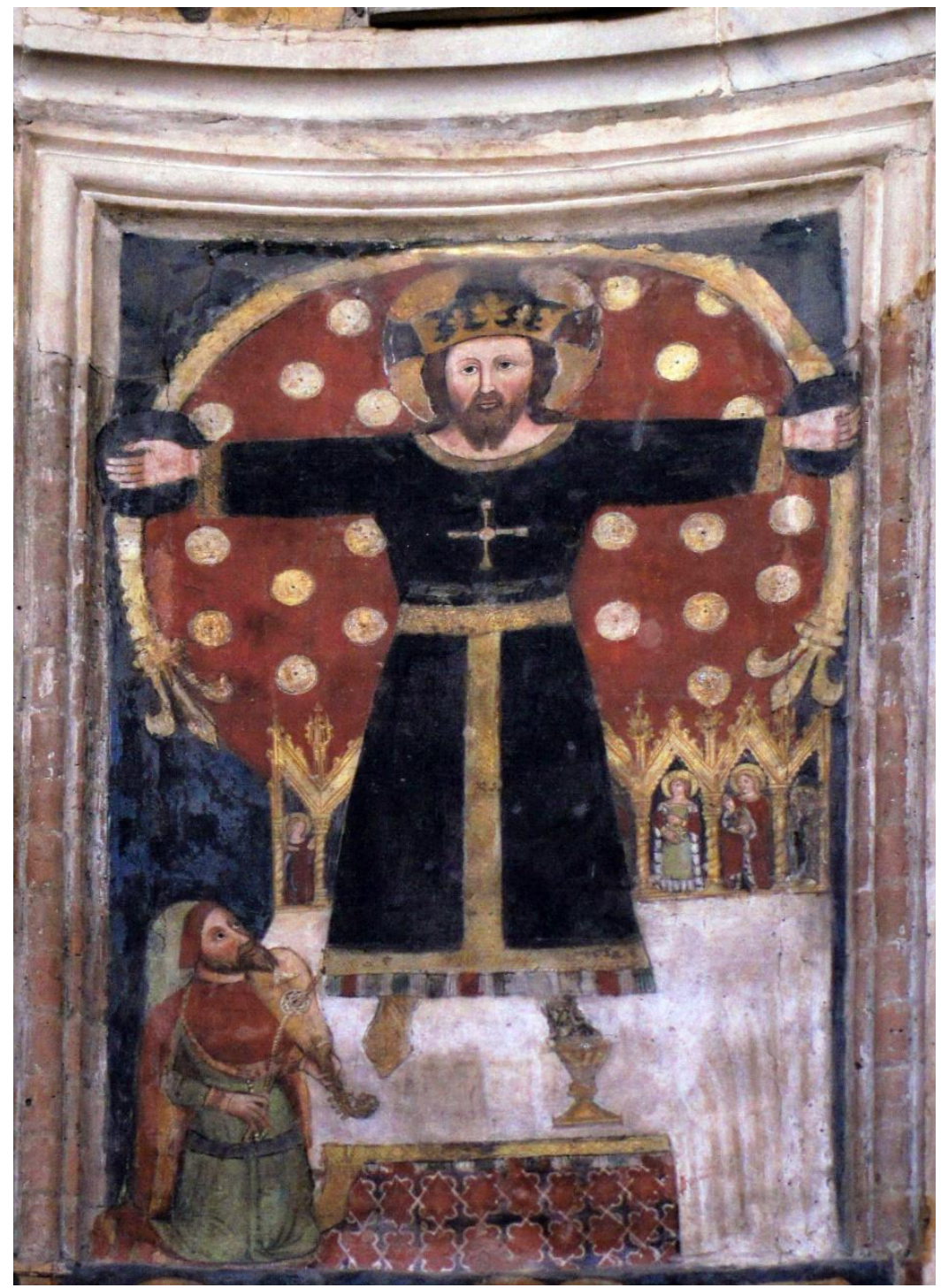

Fig. 1. Parma, Italy, Baptistery, fresco from the fourteenth century, photo by Stefan Barutcieff 


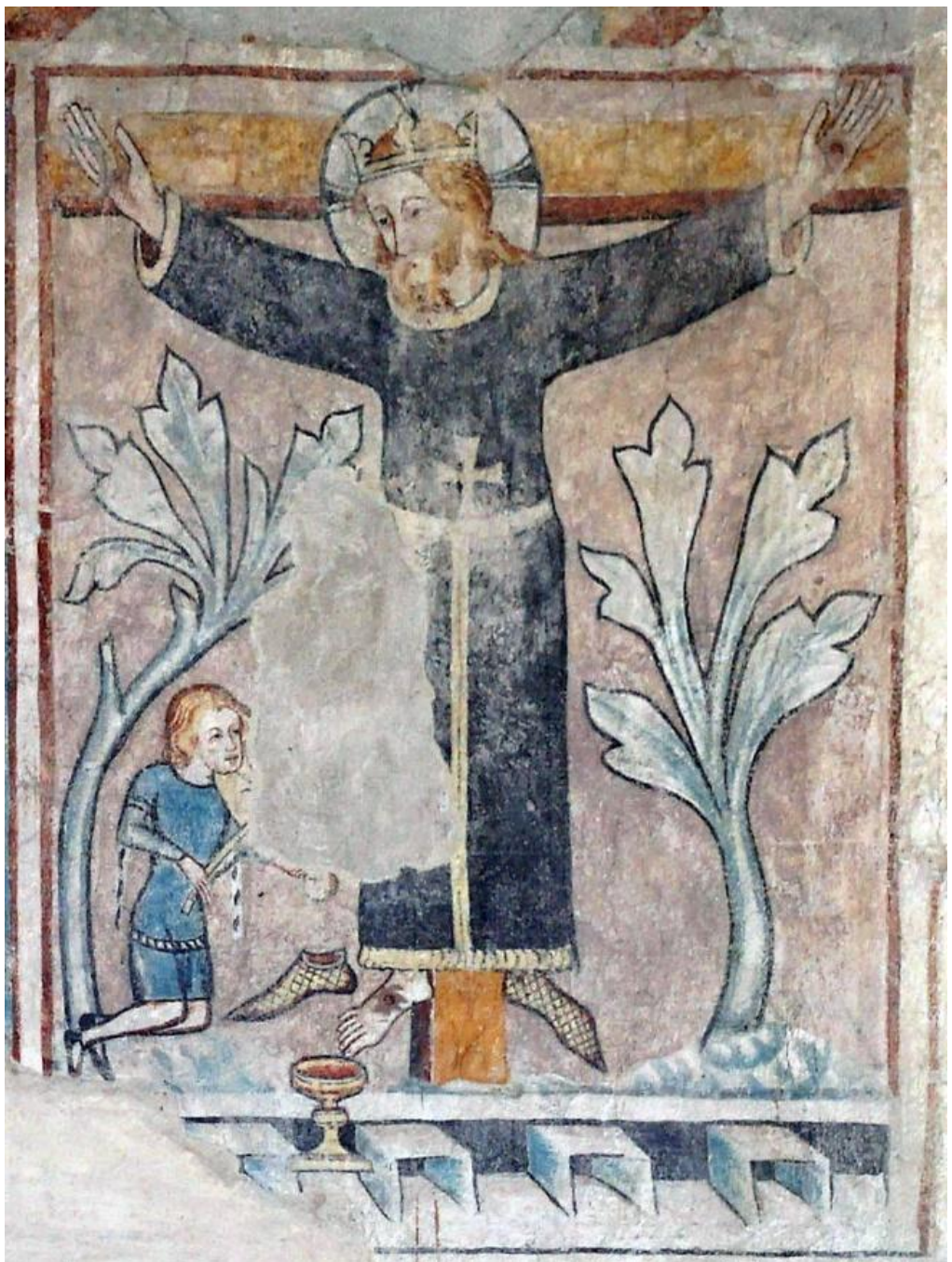

Fig. 2. Bregenz, Austria, Martin's Tower Chapel, fresco from 1363, photo by Stefan Barutcieff. 


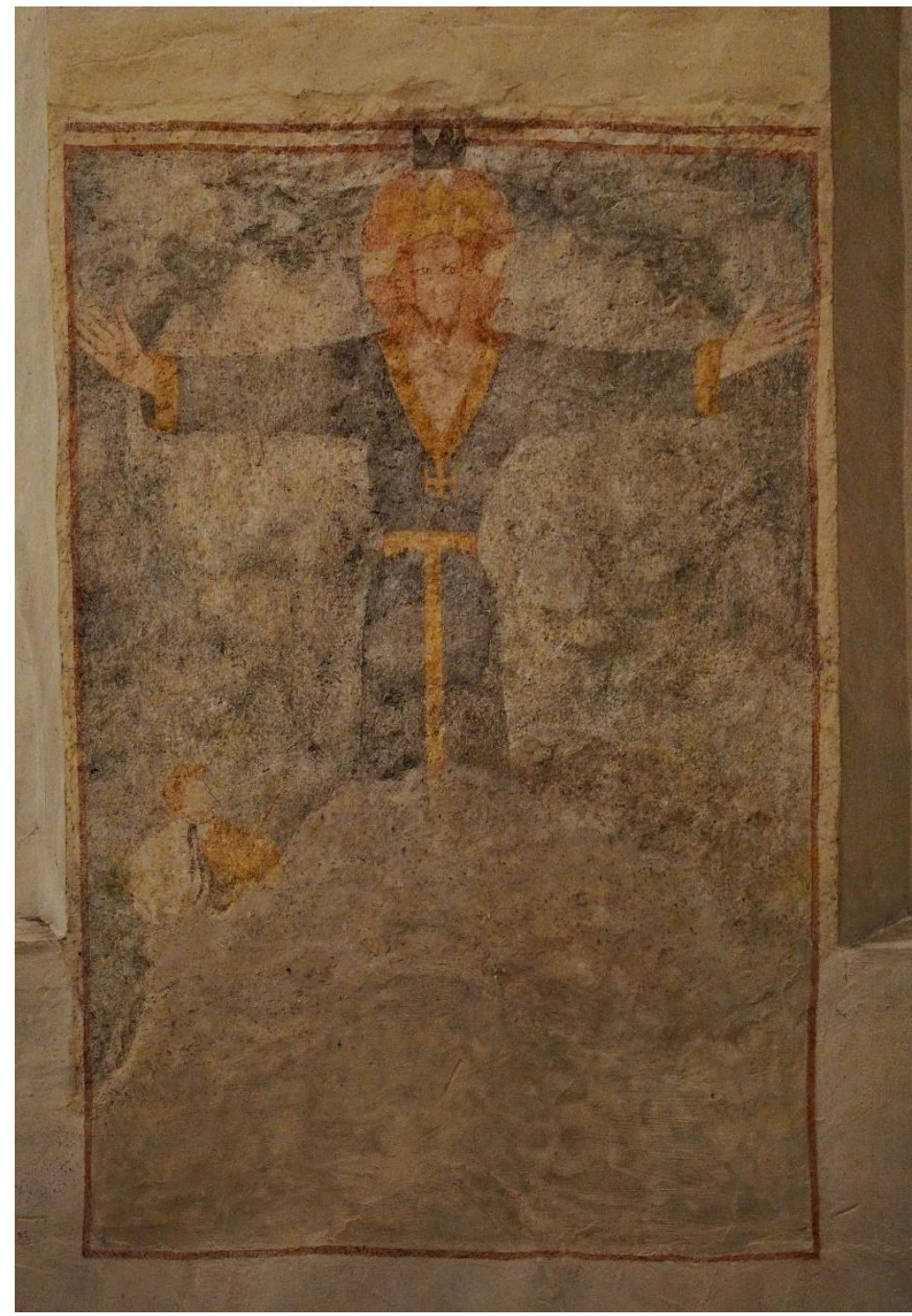

Fig. 3. Ravensburg, Germany, Lutheran Parish Church, fresco from 1470, photo by Stefan Barutcieff 


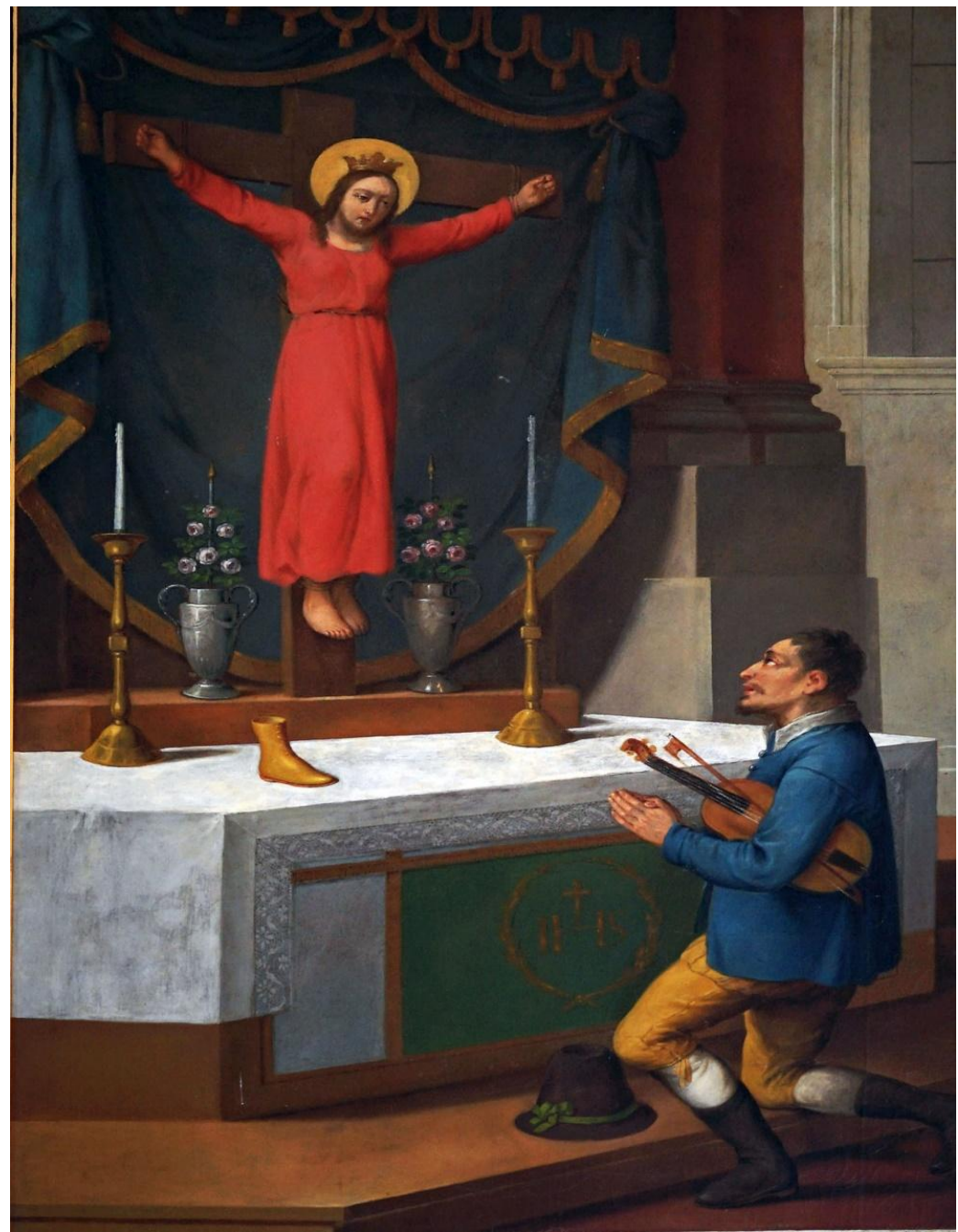

Fig. 4. Hilgertshausen, Germany, St. Stephan Church, oil on wood, 1689, photo by Stefan Barutcieff 


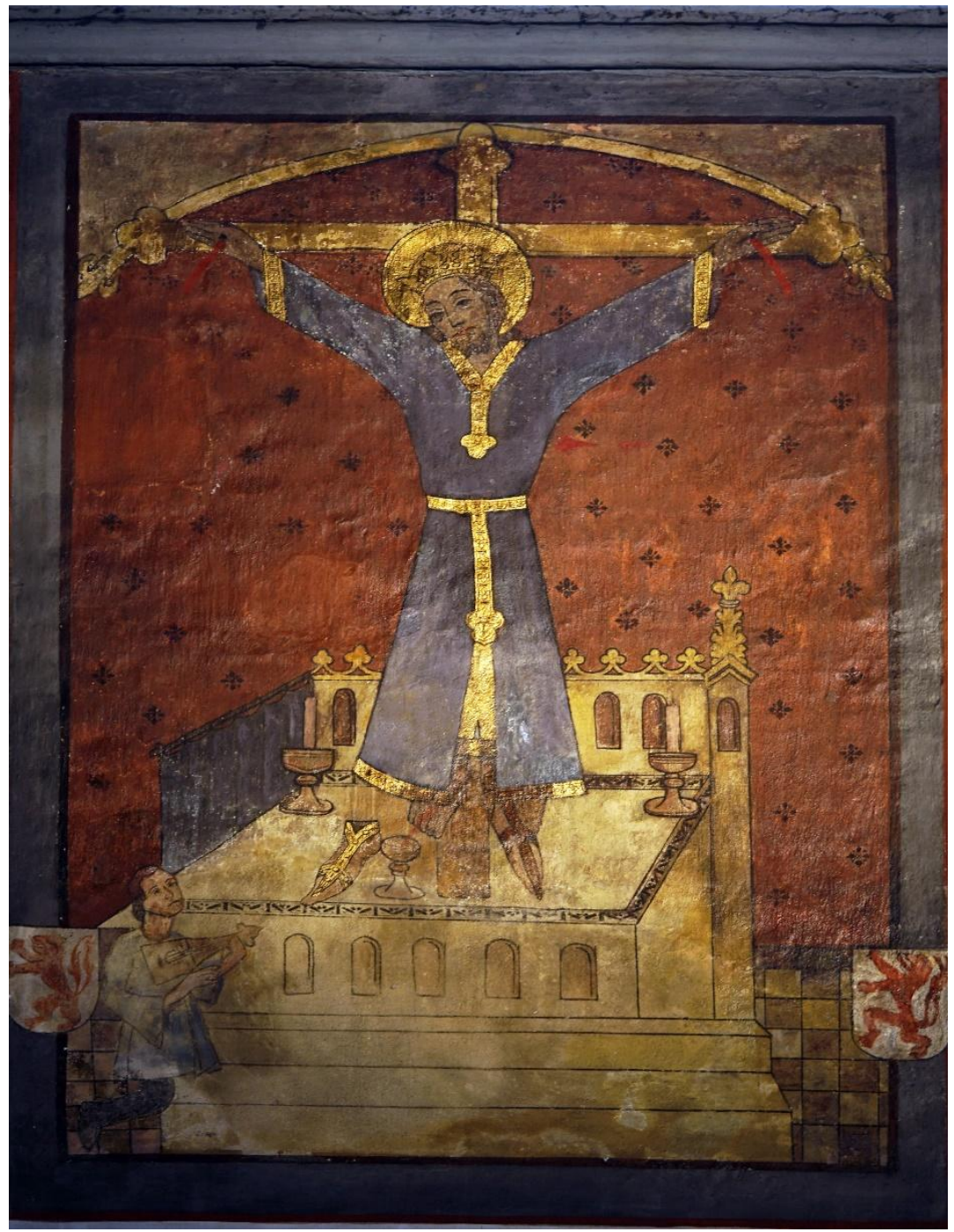

Fig. 5. Düsseldorf, Germany, St. Lambertus Church, fresco from 1460, photo by Stefan Barutcieff. 


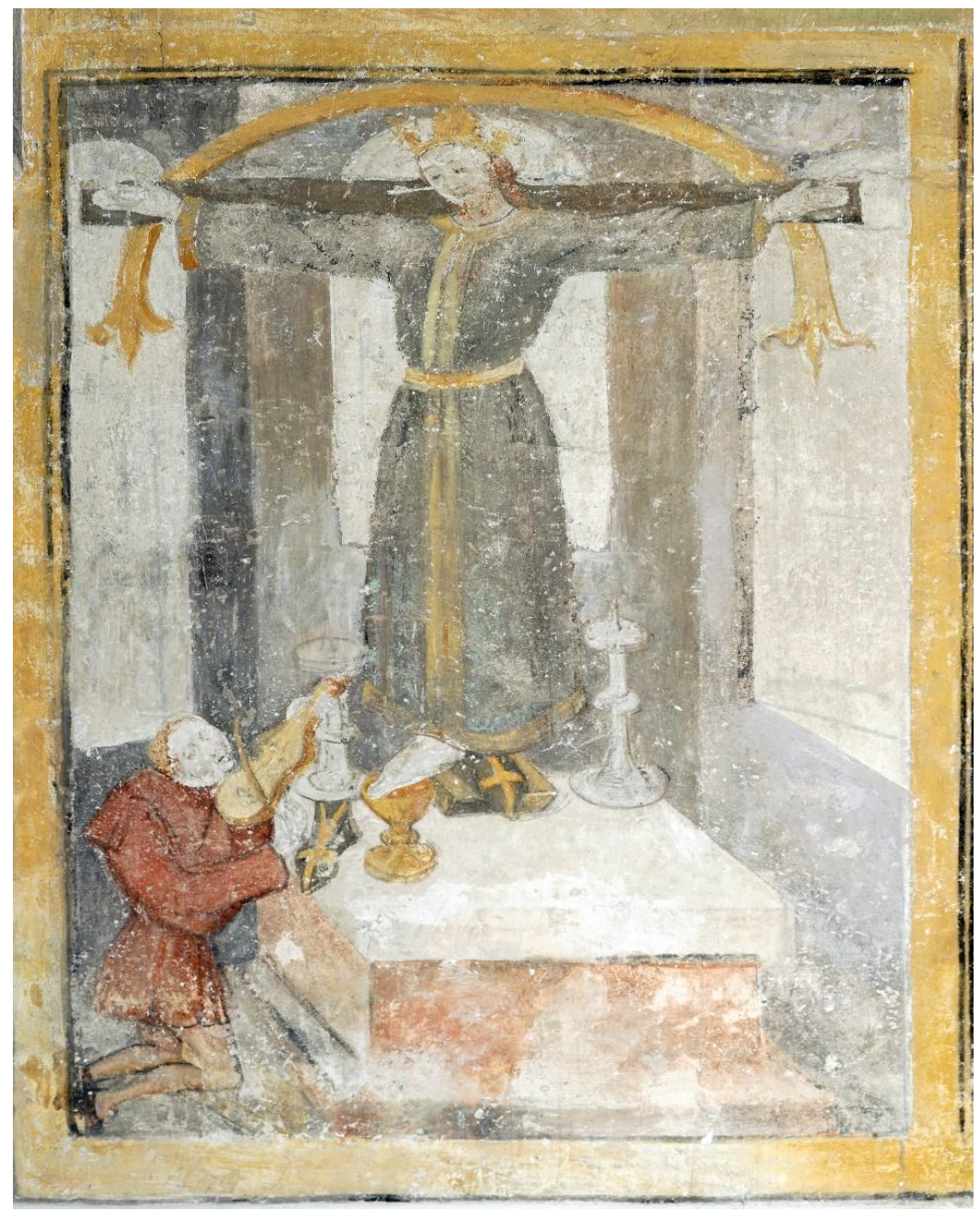

Fig. 6. Rain am Lech, Germany, St. John the Baptist, fresco c. 1480, photo by Stefan Barutcieff 